\title{
Life satisfaction of immigrants: does cultural assimilation matter?
}

\author{
Viola Angelini · Laura Casi • Luca Corazzini
}

Received: 14 May 2014 / Accepted: 12 February 2015/

Published online: 17 March 2015

(C) The Author(s) 2015. This article is published with open access at SpringerLink.com

\begin{abstract}
To investigate empirically the association between a direct measure of assimilation with a host culture and immigrants' subjective well-being, this study uses data from the German Socio-Economic Panel. A positive, significant association arises between cultural assimilation and immigrants' life satisfaction, even after controlling for several potential confounding factors, such as immigrants' individual (demographic and socio-economic) characteristics and regional controls that capture their external social conditions. Finally, the strength of the association varies with time since migration; it is significant for "established" and second-generation immigrants but vanishes for "recent" immigrants.
\end{abstract}

Keywords Cultural assimilation · Life-satisfaction · Immigration

JEL Classification $\mathrm{J} 15 \cdot \mathrm{I} 31 \cdot \mathrm{Z} 10 \cdot \mathrm{F} 22$

Responsible editor: Klaus F. Zimmermann

V. Angelini $(\square)$

Department of Economics, Econometrics and Finance, University of Groningen, Nettelbosje 2, 9747 AE Groningen, The Netherlands

e-mail: v.angelini@rug.nl

L. Casi · L. Corazzini

ISLA, Bocconi University, Via Roentgen 1, 20136 Milan, Italy

L. Casi

e-mail: laura.casi@unibocconi.it

L. Corazzini

Department of Law Science and History of Institutions, University of Messina, Piazza XX Settembre 4, 98122 Messina, Italy

e-mail: lcorazzini@unime.it 


\section{Introduction}

The assimilation of immigrants into the culture of their host country represents one of the most pertinent issues facing national policy makers. In the European Union (EU), immigration represents an important phenomenon. According to the latest Organisation for Economic Co-operation and Development (OECD) International Migration Outlook(Organisation for Economic Co-operation and Development 2013), increased migration flows in 2011-2012 mainly consisted of people moving within the EU, and Germany is the top destination. Although these waves of immigration may be temporary phenomena stemming from the global economic downturn, the effects on the social and economic status of the host countries might be persistent. ${ }^{1}$

When people migrate to a new country, they bring with them resources, habits, and experiences from their home country, including valuable productive inputs (e.g., labor, skills, other sources of human capital) that can generate substantial economic returns for the host country. ${ }^{2}$ Yet, they also enter this new society with (potentially) different cultural backgrounds, marked by distinct languages, religions, and (economic and social) values. Unfortunately, cultural exchanges triggered by migration flows sometimes are associated with dissimilation and segregation, which exert detrimental (social and economic) effects on both natives and immigrants. ${ }^{3}$ In an analysis of data from the National Identity Survey during 1995-2003, Bianchi et al. (2012) determine that the majority of natives in OECD countries express worries about the impact of migration inflows on their social security; the proportion of respondents noting concerns ranged from as low as $40 \%$ in the UK to as high as $80 \%$ in Norway (see also Martinez and Lee 2000; Bauer et al. 2000). ${ }^{4}$ According to the 2008 European Social Survey (OECD, 2010) almost $50 \%$ of Germans believe that immigrants have not had positive effects on the national economy. A recent poll comparing immigration perceptions across the UK and Germany confirmed that about $20 \%$ of Germans feel that immigration is the most pressing issue facing the country, compared with $40 \%$ in the UK. ${ }^{5}$

\footnotetext{
${ }^{1}$ Germany also was the EU country most affected by the large, intra-European displacement that followed World War II. Massive migration inflows represented an important source of low-skilled workers that sustained its rapid industrialization process. However, many of these immigrants settled there permanently, driving a second wave of immigration to achieve family reunification (Frattini and Dustmann 2013).

${ }^{2}$ For a brilliant treatise on the determinants and policy implications of migration, see Constant and Zimmermann (2013).

${ }^{3}$ On October 16, 2010, during a meeting of the Christian Democratic Union, German Prime Minister Angela Merkel contributed to the controversial multiculturalism debate by asserting, "the approach [to build] a multicultural [society] and to live side-by-side and to enjoy each other ... has failed, utterly failed." See http://www.bbc.co.uk/news/world-europe-11559451. Similar concerns about the cultural dissimilation of immigrants have been expressed by the English Prime Minister David Cameron and former French President Nicolas Sarkozy. See http://www.nytimes.com/2011/02/06/world/europe/06britain.html?_r=0.

${ }^{4}$ Card et al. (2012) measure the relative impact of economic and compositional concerns (social tensions, importance of shared religious beliefs, language, traditions, customs) on opinions about immigration policies in European countries. Compositional concerns emerge as substantially more important than economic concerns for explaining variation in individual attitudes toward immigration policies.

${ }^{5}$ See "Immigration poll finds stark difference in British and German attitudes", The Guardian, 26 November 2014 (http://www.theguardian.com/uk-news/2014/nov/26/immigration-germany-britain-starkdifference-ipsos-mori)
} 
Psychology and sociology research, in turn, analyzes the negative effects of perceived discrimination and cultural dissimilation on the social stress and mental health of immigrants (Thomas and Hughes 1986; Vega and Rumbaut 1991; Rumbaut 1994; Finch et al. 2000; Taylor and Turner 2002; Sellers et al. 2003; Hughes and Demo 1989). Social conflict between natives and specific communities of immigrants in major European countries highlight the potential damage that can result from neglecting the effects of cultural dissimilation, including unsustainable social conditions and substantial economic losses. ${ }^{6}$

Despite extensive analyses of the effects of migration flows on equilibrium conditions for the labor market of the host country (Harris and Todaro 1970; Borjas 1994; Ortega 2000), only recently have social scientists started to recognize the economic value of harmonious cultural diversity (see Ottaviano and Peri 2006; Bisin et al. 2011) and the importance of cultural, linguistic, and ethnic homogeneity in determining people's openness to immigrants (Card et al. 2012).

We therefore take an immigrant perspective to investigate the association between assimilation with the host culture and subjective well-being, drawing data from ten waves of the German Socio-Economic Panel (SOEP), a longitudinal data set that provides information about both economic (income, labor status) and non-economic (demographic, education, health) conditions. It also asks immigrants to self-report (on a 5-point scale) their assimilation with the culture of their host country, that is, their perceived closeness with a German and with their foreign identity, as well as their proficiency with German and their native language. Thus, we depart from an empirical tradition that uses indirect measures, such as the wage gap between natives and immigrants or time since migration (see Chiswick 1978; Carliner 1980; Pischke 1992; Licht and Steiner 1994; Schmidt 1993, 1997; Bauer et al. 2005; Constant and Massey 2005; Fertig and Schurer 2007; Gundel and Peters 2007), to rely on a more direct, subjective measure of perceived assimilation. ${ }^{7}$

Using self-reported measures of well-being and cultural assimilation raises some additional methodological issues, mainly related to the effects of unobserved individual heterogeneity on econometric estimates. Therefore, we rely on data gathered over multiple years so that we can control for differences in reporting styles across respondents and unobserved time-invariant personality traits. Nor is our study the first to use subjective measures of assimilation as determinants of immigrants' living conditions. Also using the SOEP data set, Casey and Dustmann (2010) study the relationship between labor market outcomes (income and labor force participation) and the extent to which immigrants identify with the culture of the host country rather than their native country. Their findings indicate the strong transmission of identity across

\footnotetext{
${ }^{6}$ See "German Turkish minority: two unamalgamated worlds" (http://www.economist.com/node/ 10958534), as well as "An underclass rebellion" (http://www.economist.com/node/5138990) for an assessment of France, and "Immigration in Italy: southern misery" (http://www.economist.com/node/15271071), covering a cruel race riot in Italy in 2010.

${ }^{7}$ Assimilation by immigrants has several manifestations: economic (convergence in incomes), cultural (host language proficiency, acquiring the host nation's identity), and "exogamous" marriages (marrying a native, see Kantarevic, 2004), for example. We do not distinguish among these aspects, because we can rely on the direct, self-reported measures of cultural assimilation.
} 
generations of immigrants but weak (non-significant) effects of cultural assimilation on economic outcomes. Combining information on language proficiency, ethnic selfidentification, and other individual domains contained in the SOEP data set, Constant and Zimmermann (2008, 2009a) also define a subjective measure of the intensity of immigrants' ethnic identity, the ethnosizer. With it, they classify migrants into four states: assimilation (strong identification with the host culture, weak identification with the culture of origin), integration (strong identification with both host and origin cultures), marginalization (strong detachment from both host and origin cultures), or separation (weak identification with the host culture, strong identification with the culture of origin). This status largely depends on pre-migration characteristics and is exogenous to immigrants' work intensity. Furthermore, young migrants tend to be better assimilated or integrated than older migrants; Muslims and Christians do not integrate but assimilate best; and immigrants who attended college in their home country separate less. Other studies (Constant et al. 2006, 2009; Zimmerman 2007; Constant and Zimmerman 2008) affirm positive, significant impacts of assimilation with the host culture on economic behavior (e.g., work probability, earnings, home ownership). ${ }^{8}$

Although motivated by the same interest in the effects of assimilation, we depart from previous studies by proposing that labor outcomes provide only a partial description of the conditions of immigrants. As economic literature suggests (see Frey and Stutzer 2002a, b; van Praag and Ferrer-i-Carbonell 2004; Bruni and Porta 2005; Dolan et al. 2008), money is not enough to make people happy; in addition to economic factors, non-economic dimensions play a crucial role in determining subjective well-being. Accordingly, we uncover the positive, strong association of cultural assimilation with immigrants' subjective well-being. Identifying with one's own culture of origin exerts only marginally significant effects for specific categories of respondents, but the self-reported level of life satisfaction is positively and significantly associated with the extent to which immigrants identify with the German culture and can communicate in German language.

This main result is robust to several specifications that account for potential confounding factors. First, we control for multiple individual dimensions, including the respondent's demographic, educational, social, economic, and health conditions. The positive association between assimilation with the host country and life satisfaction remains strong, even after controlling for economic dimensions (employment status and income) considered by prior literature. Our findings thus suggest that, beyond labor market conditions, a significant linkage between the life satisfaction of immigrants and their perceived cultural assimilation remains unexplored. Second, we investigate the interplay of cultural assimilation with the time since immigration (Gundel and Peters 2007; Safi 2010; Herrero et al. 2011), to assess whether the association between cultural assimilation and immigrants' subjective well-being

\footnotetext{
${ }^{8}$ Constant and Zimmermann (2009b) find that assimilation with German culture significantly increases the probability of work for male immigrants, relative to those identified as separated or marginalized. Assimilation does not offer particular advantages in the labor market compared with integration though. For female immigrants, integration instead is superior to assimilation, in terms of labor conditions.
} 
differs among "recent" immigrants, who are more likely to perceive differences between their native and German cultures; "established" immigrants who have been exposed to a long cultural assimilation process since their arrival; and second-generation immigrants. Assimilation with the German culture emerges as significantly associated with the level of life satisfaction only for established and second-generation immigrants; for recent immigrants, we instead detect a negative, significant relationship between their subjective well-being and the extent to which they identify with their native culture. This finding confirms the apparent difficulties immigrants experience when exposed to the (different) culture of the host country. Third, we check whether our result is mediated by the external social conditions of immigrants in Germany or concerns about foreigners' situation. For the former, we include a set of regional controls that capture immigrants' contributions to the society where they live, namely, the percentage of immigrants in the total population in the region and the percentage of (un)employed immigrants on the total (un)employed population in the region. For the latter, we use proxies for perceived discrimination and the lack of economic aspirations of immigrants. The estimates of these variables are significant and exhibit the expected signs, but their inclusion in the main specification does not alter the magnitude of the relationship between German identity and life satisfaction.

The rest of this article is organized as follows: Section 2 introduces the data, a simple theoretical framework we use to derive testable hypotheses, and the empirical strategy. We present the estimation results in Section 3, then conclude in Section 4 with some final considerations.

\section{Cultural assimilation and subjective well-being: testable predictions, data, and empirical strategy}

\subsection{A simple theoretical framework}

With our simple theoretical framework, we seek to better highlight the link between immigrants' assimilation into the host country culture and their subjective well-being. Our framework is based on a model proposed by Stark and Jakubek (2013) to study the interplay of integration, relative (material) deprivation, and immigrants' optimal investment in human capital. Rather than conducting a formal equilibrium analysis, we focus on the main assumptions of the original model and adapt them to our context to derive meaningful, testable hypotheses.

Consider a population of homogeneous immigrants who live in the host country, and let $F$ and $N$ denote the sets of immigrants and native agents in this country, respectively. Conducting a profitable economic and social life (i.e., finding a job, accessing fundamental public services, engaging in civic life) requires the acquisition of destination-specific human capital. Let $x$ denote the level of human capital that an immigrant can acquire; we assume $x \in\left[0,1-\theta x_{0}\right]$, where $x=1$ is the human capital of a native, and $\theta x_{0}$, where $\theta, x_{0} \in[0,1]$, represents the fraction of the stock of human capital carried by the immigrant from the country of origin that can be converted into destination-specific human capital. Acquiring destination-specific 
human capital is costly, so $c C(x)$ denotes the cost of assimilating, with $c>0$ and $C(x)$ denoting a convex function. For simplicity, we convert destination-specific human capital $\left(x+\theta x_{0}\right)$ into earnings on a one-to-one basis. In turn, we denote the subjective well-being of an immigrant with the following (separable) function of the investment in destination-specific human capital:

$$
\operatorname{SWB}(x)=Y\left(x+\theta x_{0}\right)-\gamma \mathrm{CD}\left(x+\theta x_{0}\right)-c C(x)+\mathrm{OF}
$$

The first term on the right denotes a strictly concave function that captures the well-being the immigrant obtains from income. The OF term captures other (constant) immigrant-specific factors that positively affect subjective well-being. It is the second term on the right that represents the distinctive element of the model: $\mathrm{CD}\left(x+\theta x_{0}\right)$ is cultural dissimilation with respect to the host culture, as experienced by the immigrant, and $\gamma \geq 0$ is immigrants' sensitivity to $\operatorname{CD}\left(x+\theta x_{0}\right)$. Even in this case, we assume that destination-specific human capital gets converted into cultural capital on a one-to-one basis, to simplify the model. Coherent with the original formulation proposed by Stark and Jakubek (2013), we assume that cultural dissimilation increases with the difference between the average destinationspecific human capital of each immigrant's reference group and the immigrant's own level: $\mathrm{CD}\left(x+\theta x_{0}\right)=\sum_{j \in J} \max \left(0 ; x_{j}-x-\theta x_{0}\right)$, where $x_{j}$ is the average human capital of the reference group $j$ and $J$ is the set of the reference groups. Stark and Jakubek (2013) use definitions of reference groups to distinguish non-integrated and integrated immigrants: The former includes in a reference group only fellow immigrants living in the same host country, such that $J=\{F\}$. If populations were homogeneous, the immigrant would not experience any cultural dissimilation with respect to other members of the community: $\operatorname{CD}\left(x+\theta x_{0}\right)=0$. For the latter group of integrated immigrants, both fellow immigrants and the native population represent reference groups, such that $J=\{N, F\}$. If we assume homogeneous populations and normalization of natives' human capital, immigrants only experience cultural dissimilation with respect to the native population: $\mathrm{CD}\left(x+\theta x_{0}\right)=\max \left(0 ; 1-x-\theta x_{0}\right)$.

With their original formulation, Stark and Jakubek (2013) study optimal investments in destination-specific human capital, chosen by the immigrant to maximize subjective well-being. Non-integrated immigrants, whose reference group only includes fellow immigrants, make relatively limited investments in human capital because they do not suffer any deprivation (or cultural dissimilation, in our framework) relative to natives. However, integrated immigrants, who include natives in their reference group, invest more in destination-specific human capital to reduce their material (or cultural, in our framework) gap with natives.

Although highly stylized, this theoretical framework provides meaningful, testable predictions about the association between assimilation with the host culture and the subjective well-being of immigrants. With our empirical exercise, we thus aim to assess whether cultural assimilation is positively associated with the level of subjective well-being per se, after we control for several potential confounding factors, such as the immigrant's (subjective) characteristics and other socio-economic conditions. Additional qualifications also apply when we account for the integration status of 
immigrants. As suggested by Eq. 1, we expect the association between assimilation with the host culture and subjective well-being to be stronger for integrated than for non-integrated immigrants.

\subsection{Data and empirical strategy}

To study the relationship between cultural assimilation and immigrants' subjective well-being, we used data from the German Socio-Economic Panel (SOEP), a longitudinal survey that has been collecting information about the socio-economic status, health, and well-being of private households since 1984 (see Wagner et al. 2007). An interesting aspect of this survey is that it oversamples the resident migrant population in Germany, offering a unique source of information about the living conditions of immigrants over time. These data feature heterogeneity with respect to the country of origin of immigrants; the top five origins are Turkey, ex-Yugoslavia, Greece, Italy, and Spain.

To capture subjective well-being (SWB), the questionnaire asks, "How satisfied are you with your life, all things considered?" and the responses range from 0 , indicating "completely dissatisfied," to 10, or "completely satisfied." Flourishing literature investigates the determinants of subjective well-being using self-reported evaluations of life satisfaction or happiness, and one of the most intriguing issues pertains to how the conclusions change when the focal question refers to happiness (a proxy of emotional well-being) rather than the more general concept of life satisfaction. As Kahneman and Deaton (2010, p. 16489) note, "emotional well-being (sometimes called hedonic well-being or experienced happiness) refers to the emotional quality of an individual's everyday experience-the frequency and intensity of experiences of joy, fascination, anxiety, sadness, anger, and affection that make one's life pleasant or unpleasant. Life evaluation refers to a person's thoughts about his or her life." 9 The relevance of the longitudinal dimension of the SOEP data set-which stretches over 30 years for some respondents-prompted us to focus on the more general, retrospectively oriented (rather than emotionally variable) concept of subjective well-being, measured as the self-reported level of satisfaction with life as a whole. It must be pointed out that subjective well-being measures are not exempt from potential criticisms mainly related to their validity (the degree to which these measures succeed in capturing the conditions of the respondent), reliability (the degree to which survey techniques secure consistent data upon repeated application), and comparability over time and over respondent samples (see Sachs, 2013, for a discussion of these issues). Our paper does not contribute to this methodological discussion and we rely on the established literature which validates the use and interpretation of these measures. Rather, by following Kahneman and Krueger (2006) and Layard (2005), we believe that subjective well-being measures present, in our context, two main advantages relative to standard objective indicators. First, in a policy perspective, they allow for more direct welfare analysis that can be conducted on specific

\footnotetext{
${ }^{9}$ Similar considerations have been reported by Graham and Nikolova (2015), Helliwell et al. (2013), and Ricard (2007) and Diener (1984).
} 
social groups, such as immigrants living in the host country. Second, these measures lead to a shift in emphasis from the importance of standard economic variables (such as income and job status) to more subjective and socially oriented determinants of individuals' well-being, such as social contacts and civic participation, cultural orientation and health conditions.

Next, to measure cultural assimilation, we relied on direct information about immigrants' sense of identification with the host culture and their German language proficiency. Following Casey and Dustmann (2010), we built a measure of cultural assimilation using information from a question that asked immigrants to report how strongly "German" they felt, on a scale from 1 ("not at all") to 5 ("completely"). The gauge of writing and speaking skills also used a 5-point scale, from 1 ("no knowledge at all") to 5 ("very good knowledge"). We measured language proficiency as the average of the writing and speaking scores. We also included SOEP information about immigrants' identification with the native culture and proficiency in the native language, to control for the potential interplay between host and native cultures.

Figures 1 and 2 show the Epanechnikov kernel density of life satisfaction, according to the strength of the identification with Germany and the native country, respectively. A strong score corresponds to the categories "mostly" and "completely," whereas the weak score refers to all other categories. The probability mass is more concentrated at high satisfaction levels for those with strong identification with the host country than for those with a weak German identity. Yet, the contrary is true for foreign identity: The densities in Fig. 2 look similar, but that for people with a weak home identity is more concentrated at higher levels of life satisfaction.

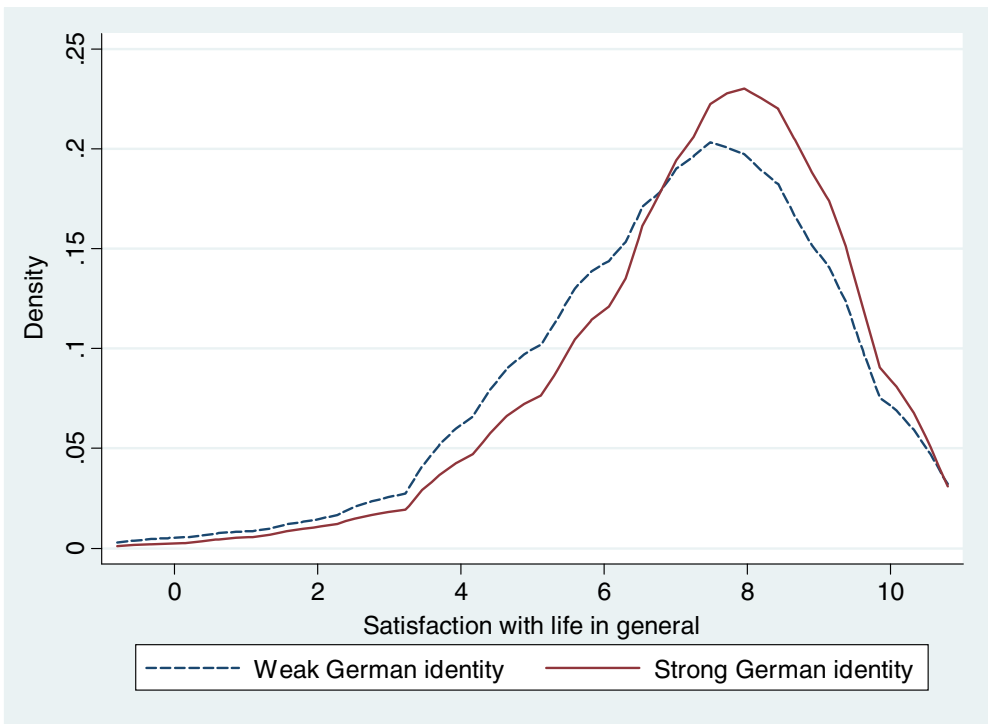

Fig. 1 Epanechnikov kernel density estimate of life satisfaction by sense of German identity (SOEP 2003). A strong score corresponds to the categories "mostly" and "completely," whereas the weak score refers to all other categories 


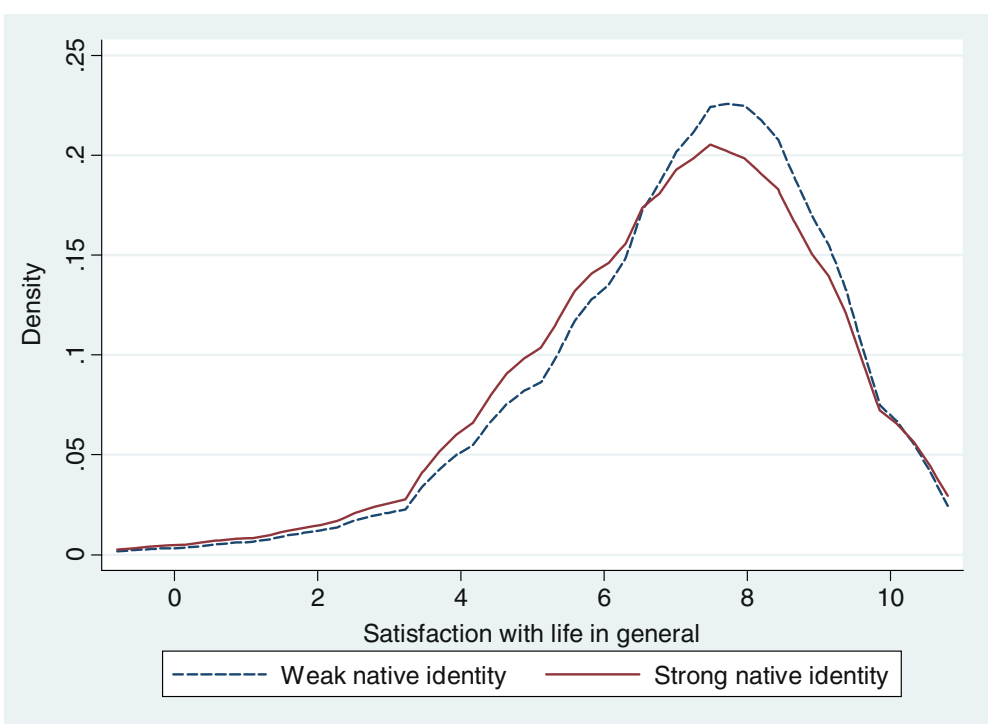

Fig. 2 Epanechnikov kernel density estimate of life satisfaction by sense of native identity (SOEP 2003). A strong score corresponds to the categories "mostly" and "completely," whereas the weak score refers to all other categories

As we show in Fig. 3, the previously documented life satisfaction gap between natives and immigrants (Baltatescu 2007; Amit 2010; Bartram 2010; Safi 2010) depends on the level of cultural assimilation of immigrants and reverses for those who feel completely integrated in German society. A Kolmogorov-Smirnov test also shows that the differences in the distributions in Figs. 1, 2, and 3 are all statistically significant at the $1 \%$ level.

These figures seem to confirm a positive relationship between cultural assimilation and immigrants' subjective well-being at a descriptive level, yet we need a more formal analysis to account for potential confounding factors. Therefore, in our empirical analysis, we focus on first- and second-generation immigrants and estimate a linear panel data model with individual and time fixed effects:

$$
\begin{gathered}
\operatorname{SWB}_{i, t}=\alpha_{i}+\alpha_{t}+w_{i t}^{\prime} \beta+\text { assimilation_host }{ }_{i t}^{\prime} \gamma+\varepsilon_{i, t} \\
\nabla i=1, \ldots, n \text { and } \nabla t=1, \ldots, T
\end{gathered}
$$

where $i=1, \ldots, n$ indicates individual respondents; $t=1, \ldots, T$ indicates the survey year; and $w_{i t}$ is a vector of control variables. In line with the theoretical framework we presented in the previous subsection, we focus on the sign and significance of the $\gamma$ parameters and test whether assimilation with the host culture is positively and significantly associated with immigrants' subjective well-being, $\gamma>0$.

With individual and time fixed effects (FE), we control for time-invariant, unobserved, individual heterogeneity and time-related common shocks. The first component, individual FE, is crucial for addressing potential differences in reporting styles across respondents (Angelini et al. 2014). Thus, a relevant methodological 


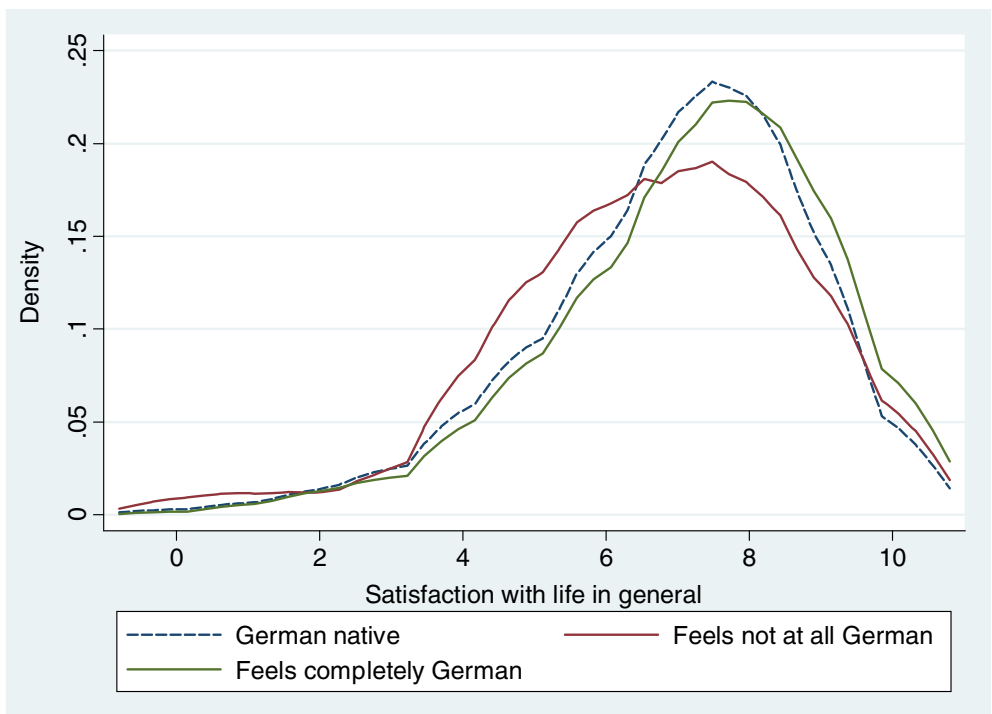

Fig. 3 Epanechnikov kernel density estimate of life satisfaction-Germans and immigrants by sense of identity (SOEP 2003)

issue is that measures of life satisfaction might not be interpersonally comparable if different people interpret and use distinct response categories for the same subjective question, a phenomenon known as differential item functioning (Holland and Wainer 1993). As long as the reporting style used by each individual respondent does not vary over time, individual fixed effects can account for this bias. Individual FE also provides a control for every unobserved factor that refers broadly to the "character" of the person, does not vary over time, and is likely to affect both self-reported life satisfaction and subjective measures of cultural assimilation, such as personal traits, optimism, religion, and ethnicity. ${ }^{10}$ The German identity variable shows substantial within-respondent variation over time: $64.55 \%$ of the immigrants in our sample show at least a one-unit change in the German identity variable during the survey period. By employing a linear specification, we also treat life satisfaction as a cardinal rather than ordinal construct, such that we can carry out the fixed effects analysis using the "within" estimator for the whole sample, and the results are easier to interpret (see Clark et al. 2008). From a practical perspective, assuming cardinality or ordinality of life satisfaction has no significant effect on the results (Ferrer-i-Carbonell and Frijters 2004). ${ }^{11}$

\footnotetext{
${ }^{10}$ Potential endogeneity due to omitted variables is strongly mitigated by the use of individual FE; the sole source of remaining endogeneity is the possible reverse causality in the dynamics of cultural assimilation and life satisfaction. Ceteris paribus, being more satisfied with life could enable the immigrant to assimilate better with the culture of the host country, which might produce an upward bias in the estimates (see Casey and Dustmann 2010). However, we believe this bias exerts only a marginal effect on our results.

${ }^{11}$ With fixed effects-ordered logit, we would lose respondents whose level of life satisfaction did not change over time (see Ferrer-i-Carbonell and Frijters 2004).
} 
The individual characteristics that we control for when estimating the association between life satisfaction and cultural assimilation include the previously detailed, subjective measures of identification with the culture of origin, demographics, health, and socio-economic status. The demographic variables include a quadratic polynomial for age, ${ }^{12}$ the number of own children, a dummy that takes a value of 1 if the respondent is married, a dummy identifying divorced people, and another dummy defining whether a person has been widowed. We measure the person's objective health status as the number of annual doctor visits and a dummy that indicates whether the person spent at least one night in the hospital in the previous year. Finally, the set of variables aimed to define individual socio-economic status include income and dummies for whether the person has a full-time job, a part-time job, or is undergoing a program of vocational training (a residual category includes people who are not working at all).

Table 1 presents the descriptive statistics for all the variables we used in the regressions. The immigrants in our sample are mostly married $(72.2 \%)$ and have one child on average; $58.3 \%$ work either full- or part-time, $3.7 \%$ are in vocational training, and the remaining $38 \%$ are outside the labor force. The average immigrant is 38.9 years of age and went to the doctor three to four times in the previous year. Our final sample contains an unbalanced panel of 22,636 observations (6167 persons) from 10 survey waves over 18 years $(1985,1986,1987$, then every 2 years until 2003 , except 1993). ${ }^{13}$

In the second part of our analysis, in line with our theoretical framework, we tested whether the positive association between assimilation with the host culture and subjective well-being is stronger for integrated than non-integrated immigrants. We use the time since migration as a proxy for social integration and repeat the estimation procedure on three subsamples of immigrants: recent immigrants who have been in Germany for less than 10 years and are likely not to be fully integrated, established immigrants who migrated to Germany more than 10 years ago and have been exposed to a sufficiently long integration process since their arrival, ${ }^{14}$ and second-generation immigrants, who have only an indirect migration background.

Finally, we checked whether controlling for additional external social conditions affects the magnitude or sign of the association between cultural assimilation and life satisfaction. For this effort, we used data collected by Eurostat for the European Labour Force Survey and aggregated at the regional level. ${ }^{15}$ To measure general openness in a region to foreign-born members, we constructed indexes

\footnotetext{
${ }^{12}$ Because including individual fixed effects, year fixed effects, and age simultaneously create an obvious identification problem, we impose the restriction that the first 2 years (1985 and 1986) are equal (i.e., we drop one time dummy from the equation).

${ }^{13}$ We selected only years for which we had information about the measures of cultural assimilation.

${ }^{14}$ The 10-year threshold is somewhat arbitrary. We tried a 5-year threshold as an alternative, but that makes the sample of recent immigrants (182) too small to draw any inferences.

${ }^{15}$ The regions correspond to the NUTS1 classification: Baden-Württemberg (DE1), Bavaria (DE2), Berlin (DE3), Brandenburg (DE4), Bremen (DE5), Hamburg (DE6), Hessen (DE7), Mecklenburg-Vorpommern (DE8), Lower Saxony (DE9), North Rhine-Westphalia (DEA), Rhineland-Palatinate (DEB), Saarland (DEC), Saxony (DED), Saxony-Anhalt (DEE), Schleswig-Holstein (DEF), and Thuringia (DEG).
} 
Table 1 Descriptive statistics

Mean S.D. Min Max

Subjective well-being

Life satisfaction

$\begin{array}{lllll}\text { How satisfied the respondent is with her life } & 7.087 & 1.894 & 0 & 10\end{array}$

$(0=$ completely dissatisfied, $\ldots, 10=$ completely

satisfied)

Cultural assimilation

German identity

How strongly German the respondent feels

$2.507 \quad 1.291 \quad 1 \quad 5$

$(1=$ not at all, $\ldots, 5=$ completely $)$

Foreign identity How strongly foreign the respondent feels

$\begin{array}{llll}3.842 & 1.155 & 1 & 5\end{array}$

$(1=$ not at all, ..., 5= completely)

German proficiency Average between speaking and writing skills in

German $(1=$ poor $\ldots, 5=$ very good $)$

Native proficiency Average between speaking and writing skills in

the native language $(1=$ poor $\ldots, 5=$ very good $)$

$\begin{array}{llll}3.292 & 1.161 & 1 & 5\end{array}$

$\begin{array}{llll}4.179 & 0.858 & 1 & 5\end{array}$

Demographics

Age

Age of the respondent in years

Number of children

Number of living children

$\begin{array}{llll}38.892 & 14.280 & 15 & 94\end{array}$

$\begin{array}{llll}1.123 & 1.250 & 0 & 10\end{array}$

Marital status

Married

Dummy $=1$ if the respondent is married

$\begin{array}{llll}0.722 & 0.448 & 0 & 1\end{array}$

Divorced

Dummy $=1$ if the respondent is divorced or

$\begin{array}{llll}0.046 & 0.210 & 0 & 1\end{array}$

Widowed separated

Single

Dummy $=1$ if widow or widower

Dummy $=1$ if the respondent is single

$\begin{array}{llll}0.018 & 0.134 & 0 & 1\end{array}$

(reference category)

$\begin{array}{llll}0.214 & 0.410 & 0 & 1\end{array}$

Income

Log (income)

Logarithm of household monthly income

$\begin{array}{llll}7.440 & 0.489 & 3.258 & 10.597\end{array}$

Employment status

Full-time worker

Dummy $=1$ if working full-time

Part-time worker

Dummy $=1$ if working part-time

Vocational training

Dummy $=1$ if in vocational training

$\begin{array}{llll}0.510 & 0.500 & 0 & 1\end{array}$

Not at work

Dummy $=1$ if not working (reference category)

$\begin{array}{llll}0.073 & 0.260 & 0 & 1\end{array}$

$\begin{array}{llll}0.037 & 0.189 & 0 & 1\end{array}$

$\begin{array}{llll}0.380 & 0.485 & 0 & 1\end{array}$

Health

Hospital stay

Dummy $=1$ if at least one overnight hospital

$\begin{array}{llll}0.116 & 0.320 & 0 & 1\end{array}$ stay within the previous year

Log (doctor visits +1 ) Logarithm of the number of visits to the doctor

$1.491 \quad 1.403 \quad 0$ within the previous year $=1$

SOEP data 1986-2003, immigrant sample 
by region and year for the concentration of immigrants, defined as the percentage in the total population (Fig. 4). We also split this general index into the concentration of (un)employed immigrants, defined as the percentage of (un)employed immigrants on the total un(employed) population. If immigrants contribute actively to the host society through the labor force, society should be more open to them, such that nonnatives should feel more accepted overall. These data are available only since 1995 , and when we introduce them in the analysis, our sample drops to 11,262 observations (4444 persons). On average, immigrants represent about $10 \%$ of the total population and $21 \%(9 \%)$ of the unemployed (employed) population in Germany.

The regions hosting more immigrants relative to their population are concentrated in south-west Germany-the richest area of the country. Probably due to their historical heritage, characterized by closed attitudes toward external influences, and the renewed strength of anti-immigration political parties, the northeast regions instead display a very low concentration of immigrants. More recent years of the SOEP also provide information about the extent to which immigrants are concerned about the

\section{Immigrant penetration in German Regions}

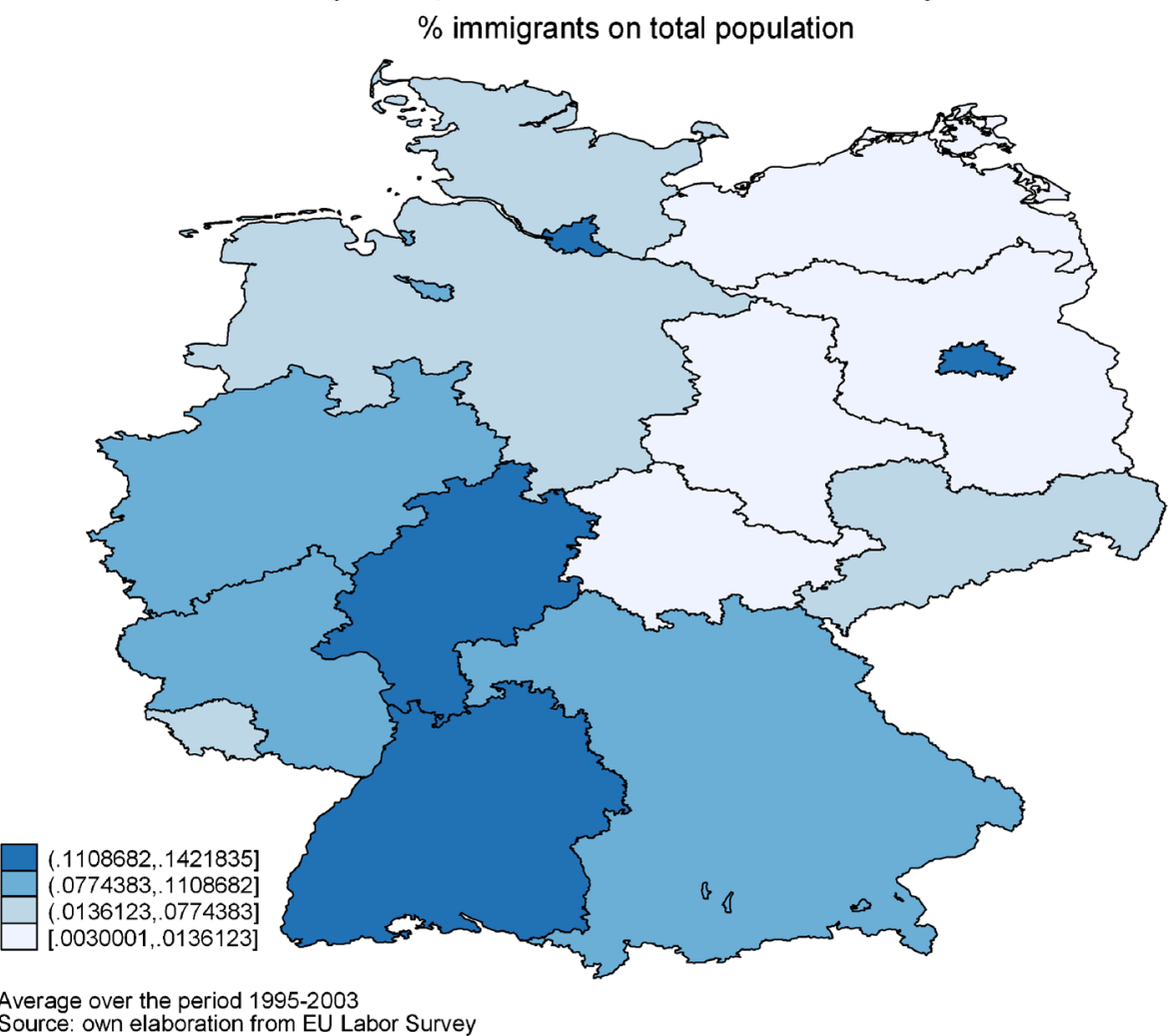

Average over the period $1995-2003$
Source: own elaboration from EU Labor Survey

Fig. 4 Total immigrant concentration in German regions (European Labour Force Survey 1995-2003 average) 
situation for foreigners in Germany. On average, $32.8 \%$ of immigrants are very concerned, though this variable shows a downward trend over time, with the exception of a temporary increase in 2001 , probably due to the $9 / 11$ attacks.

\section{Results}

We present our main estimation results in Table 2. In the first column, we start by estimating a life satisfaction equation in which we control for standard determinants of subjective well-being. Our findings are consistent with prior literature, confirming the importance of economic conditions for determining immigrants' well-being, in that people with higher income and in full-time employment are better off on average in terms of life satisfaction. However, non-economic factors also play a crucial role. In particular, poor health conditions relate strongly and negatively to life satisfaction. In terms of demographics, we find a U-shaped relationship between age and life satisfaction, with a minimum age around 52 years, as in Blanchflower and Oswald (2008). Being married is positively associated with life satisfaction; the number of children does not seem to affect the well-being of immigrants though.

In the next columns, we shift to our main analysis focus: the relationship between assimilation with the host culture and the subjective well-being of immigrants. For this assessment, we introduce measures of ethnic identity (German and foreign identity) and language proficiency. The results support our main theoretical prediction, because after we control for the traditional determinants of life satisfaction and individual and time fixed effects, stronger (perceived) assimilation with the host culture is associated with higher levels of life satisfaction. The sense of belonging to the German culture is very important, but identifying with the native culture does not have significant effects on life satisfaction. ${ }^{16}$ This result is substantively meaningful; it implies that moving from not feeling at all German to feeling completely German has 1.2 times the impact on life satisfaction as does being married (column 3). Being able to interact with local citizens also is very important, such that German language proficiency has a strong, significant, positive effect on immigrants' well-being, even when we control for socio-economic conditions and labor market status. Importantly, as we control for time-invariant personality traits and response styles by including individual fixed effects, our results are not driven by spurious correlations of cultural assimilation and life satisfaction. ${ }^{17}$

These results also can inform existing literature about immigrants' enclaves and social integration. Danzer and Yaman (2013) show that by limiting immigrants' civic participation and interactions with native populations, ethnic enclaves in Germany significantly reduce their cultural assimilation. Dustmann (1996) documents that immigrants from more distant cultural backgrounds (e.g., Turks, Greeks) exhibit

\footnotetext{
${ }^{16}$ German and foreign identity correlate negatively. If we introduce them separately in the estimation (one or the other), native identity has a very small, negative, significant effect on life satisfaction, whereas the coefficient for German identity remains unaltered.

${ }^{17}$ The Hausman test always rejects the null hypothesis ( $p$ value $=0.000$ in all three columns) and therefore, confirms that fixed effects are appropriate.
} 
Table 2 Life satisfaction of immigrants (SOEP data 1985-2003)_estimation with individual and time FE
Variables

\begin{tabular}{|c|c|c|c|}
\hline \multicolumn{4}{|l|}{ Variables } \\
\hline German identity & & $\begin{array}{l}0.097 * * * \\
(0.018)\end{array}$ & $\begin{array}{l}0.085^{* * *} \\
(0.018)\end{array}$ \\
\hline Foreign identity & & $\begin{array}{c}0.006 \\
(0.019)\end{array}$ & $\begin{array}{c}0.003 \\
(0.019)\end{array}$ \\
\hline German proficiency & & & $\begin{array}{l}0.166^{* * * *} \\
(0.027)\end{array}$ \\
\hline Native proficiency & & & $\begin{array}{l}0.097 * * * \\
(0.024)\end{array}$ \\
\hline Age & $\begin{array}{c}-0.104 * * \\
(0.050)\end{array}$ & $\begin{array}{c}-0.108 * * \\
(0.050)\end{array}$ & $\begin{array}{c}-0.104 * * \\
(0.050)\end{array}$ \\
\hline Age squared & $\begin{array}{l}0.001 * * * \\
(0.000)\end{array}$ & $\begin{array}{l}0.001 * * * \\
(0.000)\end{array}$ & $\begin{array}{l}0.001 * * * \\
(0.000)\end{array}$ \\
\hline Married & $\begin{array}{l}0.246^{* * *} \\
(0.086)\end{array}$ & $\begin{array}{l}0.260 * * * \\
(0.085)\end{array}$ & $\begin{array}{l}0.280 * * * \\
(0.085)\end{array}$ \\
\hline Divorced & $\begin{array}{r}-0.014 \\
(0.153)\end{array}$ & $\begin{array}{r}-0.003 \\
(0.152)\end{array}$ & $\begin{array}{c}0.010 \\
(0.151)\end{array}$ \\
\hline Widowed & $\begin{array}{r}-0.188 \\
(0.336)\end{array}$ & $\begin{array}{r}-0.187 \\
(0.333)\end{array}$ & $\begin{array}{r}-0.140 \\
(0.334)\end{array}$ \\
\hline Number of children & $\begin{array}{c}0.017 \\
(0.020)\end{array}$ & $\begin{array}{c}0.015 \\
(0.020)\end{array}$ & $\begin{array}{c}0.015 \\
(0.020)\end{array}$ \\
\hline Log (income) & $\begin{array}{l}0.272 * * * \\
(0.046)\end{array}$ & $\begin{array}{l}0.271^{* * *} \\
(0.046)\end{array}$ & $\begin{array}{l}0.270 * * * \\
(0.046)\end{array}$ \\
\hline Full-time worker & $\begin{array}{l}0.422 * * * \\
(0.051)\end{array}$ & $\begin{array}{l}0.419 * * * \\
(0.051)\end{array}$ & $\begin{array}{l}0.407 * * * \\
(0.050)\end{array}$ \\
\hline Part-time worker & $\begin{array}{l}0.215 * * * \\
(0.064)\end{array}$ & $\begin{array}{l}0.213 \text { *** } \\
(0.064)\end{array}$ & $\begin{array}{l}0.202 * * * \\
(0.064)\end{array}$ \\
\hline Vocational training & $\begin{array}{l}0.272 * * * \\
(0.078)\end{array}$ & $\begin{array}{l}0.276^{* * *} \\
(0.077)\end{array}$ & $\begin{array}{l}0.277 * * * \\
(0.077)\end{array}$ \\
\hline Hospital stay & $\begin{array}{c}-0.120 * * * \\
(0.043)\end{array}$ & $\begin{array}{c}-0.120 * * * \\
(0.042)\end{array}$ & $\begin{array}{c}-0.123^{* * * *} \\
(0.042)\end{array}$ \\
\hline $\log ($ doctor visits +1$)$ & $\begin{array}{c}-0.084 * * * \\
(0.011)\end{array}$ & $\begin{array}{c}-0.083^{* * * *} \\
(0.011)\end{array}$ & $\begin{array}{c}-0.084 * * * \\
(0.011)\end{array}$ \\
\hline Constant & $\begin{array}{l}7.760 * * * \\
(1.552)\end{array}$ & $\begin{array}{l}7.597 * * * \\
(1.556)\end{array}$ & $\begin{array}{l}6.541 * * * \\
(1.560)\end{array}$ \\
\hline Observations & 22,636 & 22,636 & 22,636 \\
\hline Number of individuals & 6167 & 6167 & 6167 \\
\hline Within $R^{2}$ & 0.043 & 0.045 & 0.050 \\
\hline
\end{tabular}

Robust standard errors in parentheses $(* * * p<0.01$, $* * p<0.05, * p<0.1)$. Immigrants who never married and are not employed are the reference group

a lower assimilation tendency into German society. Language proficiency and education are other important determinants of cultural assimilation, as is labor market integration (Dustmann, 1994, 1996). In light of this literature, our results highlight the 
Table 3 Life satisfaction of immigrants (SOEP data 1985-2003) by migration background and years since migration-estimation with individual and time FE

\begin{tabular}{|c|c|c|c|}
\hline Variables & 10 years or less & More than 10 years & Second generation \\
\hline German identity & $\begin{array}{c}0.069 \\
(0.056)\end{array}$ & $\begin{array}{l}0.074 * * * \\
(0.022)\end{array}$ & $\begin{array}{l}0.124 * * \\
(0.049)\end{array}$ \\
\hline Foreign identity & $\begin{array}{c}-0.128 * * \\
(0.052)\end{array}$ & $\begin{array}{c}0.035 \\
(0.024)\end{array}$ & $\begin{array}{r}-0.025 \\
(0.049)\end{array}$ \\
\hline German proficiency & $\begin{array}{l}0.150 * * \\
(0.069)\end{array}$ & $\begin{array}{l}0.183 * * * \\
(0.033)\end{array}$ & $\begin{array}{l}0.228 * * * \\
(0.076)\end{array}$ \\
\hline Native proficiency & $\begin{array}{c}0.030 \\
(0.064)\end{array}$ & $\begin{array}{l}0.111^{* * *} \\
(0.030)\end{array}$ & $\begin{array}{c}0.091 * \\
(0.054)\end{array}$ \\
\hline Age & $\begin{array}{r}-0.167 \\
(0.129)\end{array}$ & $\begin{array}{r}-0.082 \\
(0.061)\end{array}$ & $\begin{array}{c}-0.648^{* * *} \\
(0.191)\end{array}$ \\
\hline Age squared & $\begin{array}{c}0.001 \\
(0.001)\end{array}$ & $\begin{array}{l}0.000 * * \\
(0.000)\end{array}$ & $\begin{array}{l}0.005^{* * *} \\
(0.001)\end{array}$ \\
\hline Married & $\begin{array}{c}0.264 \\
(0.235)\end{array}$ & $\begin{array}{c}0.214 * \\
(0.128)\end{array}$ & $\begin{array}{l}0.550 * * * \\
(0.156)\end{array}$ \\
\hline Divorced & $\begin{array}{c}0.094 \\
(0.413)\end{array}$ & $\begin{array}{r}-0.011 \\
(0.202)\end{array}$ & $\begin{array}{c}0.557 \\
(0.352)\end{array}$ \\
\hline Widowed & $\begin{array}{c}1.145 \\
(1.350)\end{array}$ & $\begin{array}{r}-0.152 \\
(0.407)\end{array}$ & $\begin{array}{c}0.087 \\
(0.266)\end{array}$ \\
\hline Number of children & $\begin{array}{c}0.054 \\
(0.069)\end{array}$ & $\begin{array}{c}0.016 \\
(0.025)\end{array}$ & $\begin{array}{r}-0.091 * \\
(0.054)\end{array}$ \\
\hline $\log$ (income) & $\begin{array}{c}0.161 \\
(0.121)\end{array}$ & $\begin{array}{l}0.292 * * * \\
(0.061)\end{array}$ & $\begin{array}{c}0.145 \\
(0.101)\end{array}$ \\
\hline Full-time worker & $\begin{array}{l}0.752 * * * \\
(0.135)\end{array}$ & $\begin{array}{l}0.460 * * * \\
(0.064)\end{array}$ & $\begin{array}{l}0.312 * * * \\
(0.116)\end{array}$ \\
\hline Part-time worker & $\begin{array}{c}0.303 * \\
(0.172)\end{array}$ & $\begin{array}{l}0.255^{* * *} \\
(0.085)\end{array}$ & $\begin{array}{c}0.216 \\
(0.142)\end{array}$ \\
\hline Vocational training & $\begin{array}{c}0.231 \\
(0.205)\end{array}$ & $\begin{array}{l}0.509 * * * \\
(0.138)\end{array}$ & $\begin{array}{c}0.161 \\
(0.112)\end{array}$ \\
\hline Hospital stay & $\begin{array}{c}0.043 \\
(0.104)\end{array}$ & $\begin{array}{c}-0.164 * * * \\
(0.053)\end{array}$ & $\begin{array}{r}-0.020 \\
(0.130)\end{array}$ \\
\hline $\log ($ doctor visits +1$)$ & $\begin{array}{r}-0.041 \\
(0.028)\end{array}$ & $\begin{array}{c}-0.082 * * * \\
(0.013)\end{array}$ & $\begin{array}{c}-0.069 * * \\
(0.030)\end{array}$ \\
\hline Constant & $\begin{array}{l}9.513 * * * \\
(3.084)\end{array}$ & $\begin{array}{l}5.732 * * * \\
(2.149)\end{array}$ & $\begin{array}{l}13.957 * * * \\
(2.803)\end{array}$ \\
\hline Observations & 4135 & 14,983 & 2642 \\
\hline Number of individuals & 1987 & 3881 & 938 \\
\hline Within $R^{2}$ & 0.040 & 0.052 & 0.090 \\
\hline
\end{tabular}

Robust standard errors in parentheses $(* * * p<0.01, * * p<0.05, * p<0.1$ ). Immigrants who never married and are not employed are the reference group 
importance of discouraging the creation of ethnic enclaves but supporting host country language proficiency. Such actions can foster immigrants' cultural assimilation per se and also benefit their indirect association for their well-being.

In Table 3, we present the results of a repeated analysis with the three subsamples, defined according to their migration background, in which we sought to address the interplay of assimilation with the host culture and time since migration (Gundel and Peters 2007; Safi 2010; Herrero et al. 2011). In line with our second testable prediction, assimilation with German culture is significantly associated with the level of life satisfaction of established and second-generation immigrants only. Among recent immigrants, we instead detect a negative and significant relationship between subjective well-being and the extent to which they identify with their native culture, confirming the difficulties experienced by immigrants upon their exposure to the (different) culture of the host country. Cultural assimilation matters especially in the long run though, and effective integration policies might accelerate this process.

Finally, as we show in Table 4, we checked the robustness of our results after introducing controls for the social conditions in which immigrants live. In particular, spatial effects driven by regional differences in openness to foreign-born populations might determine differences in immigrants' life satisfaction, rather than a direct link between subjective perceptions of cultural assimilation and their subjective wellbeing. To understand the relative importance of these two mechanisms, we augment our prior specification to include the concentration of immigrants in each German region. In addition, the general openness of the region to foreign-born residents could affect their life satisfaction, but the potential contributions that immigrants make to the local society also might affect the interplay between cultural assimilation and their life satisfaction. Therefore, we split the index according to two variables that measure the concentration of unemployed and employed immigrants. These variables came from the European Labour Force Survey and vary by region (according to the NUTS1 European territorial classification) and year. Unfortunately, data from the European Labour Force Survey are only available since 1995, so this second part of the analysis is restricted to a relatively recent subsample of the SOEP. When focusing on these recent years, we also can control for perceived discrimination, measured with a dummy variable equal to 1 if the immigrant is "very concerned for the foreigners' situation in Germany" and 0 otherwise. ${ }^{18}$

We repeat the same estimation as in the last column of Table 2 with the new sample, to show that our findings are qualitatively the same even when we focus on a different time period. We introduce an index of immigrant concentration by region and year, measured as the percentage of immigrants in the total population of the region. With this variable, we aim to capture the extent to which the relation between cultural assimilation and life satisfaction is affected by the region's general openness to foreign-born persons. As we noted, we want to disentangle the

\footnotetext{
${ }^{18}$ This question has been asked since 1992, and the item includes three possible responses: "not concerned at all," "somewhat concerned," and "very concerned." Factoring this variable indicates that only the last category matters for determining immigrants' life satisfaction (these results are available on request). Therefore, we included only a dummy variable that equals 1 if the immigrant is "very concerned" about the situation of foreigners in Germany.
} 
Table 4 Life satisfaction of immigrants (SOEP data 1995-2003)—estimation with individual and time FE

\section{Variables}

\begin{tabular}{|c|c|c|c|c|}
\hline German identity & $\begin{array}{l}0.069 * * * \\
(0.027)\end{array}$ & $\begin{array}{l}0.069 * * * \\
(0.027)\end{array}$ & $\begin{array}{l}0.067 * * \\
(0.027)\end{array}$ & $\begin{array}{l}0.066^{* *} \\
(0.027)\end{array}$ \\
\hline Foreign identity & $\begin{array}{r}-0.018 \\
(0.026)\end{array}$ & $\begin{array}{r}-0.018 \\
(0.026)\end{array}$ & $\begin{array}{r}-0.018 \\
(0.026)\end{array}$ & $\begin{array}{r}-0.018 \\
(0.026)\end{array}$ \\
\hline German proficiency & $\begin{array}{l}0.112 \text { *** } \\
(0.037)\end{array}$ & $\begin{array}{l}0.112 * * * \\
(0.037)\end{array}$ & $\begin{array}{l}0.110 * * * \\
(0.037)\end{array}$ & $\begin{array}{l}0.109 * * * \\
(0.037)\end{array}$ \\
\hline Native proficiency & $\begin{array}{l}0.085 * * \\
(0.034)\end{array}$ & $\begin{array}{l}0.085 * * \\
(0.034)\end{array}$ & $\begin{array}{l}0.085 * * \\
(0.034)\end{array}$ & $\begin{array}{l}0.087 * * \\
(0.034)\end{array}$ \\
\hline Age & $\begin{array}{c}-0.181 * * * \\
(0.031)\end{array}$ & $\begin{array}{c}-0.181 * * * \\
(0.036)\end{array}$ & $\begin{array}{c}-0.133 * * * \\
(0.041)\end{array}$ & $\begin{array}{c}-0.131 * * * \\
(0.041)\end{array}$ \\
\hline Age squared & $\begin{array}{l}0.001^{* * * *} \\
(0.000)\end{array}$ & $\begin{array}{l}0.001^{* * * *} \\
(0.000)\end{array}$ & $\begin{array}{l}0.001^{* * * *} \\
(0.000)\end{array}$ & $\begin{array}{l}0.001 * * * \\
(0.000)\end{array}$ \\
\hline Married & $\begin{array}{l}0.399 * * * \\
(0.153)\end{array}$ & $\begin{array}{l}0.399 * * * \\
(0.153)\end{array}$ & $\begin{array}{l}0.407 * * * \\
(0.153)\end{array}$ & $\begin{array}{l}0.406^{* * * *} \\
(0.153)\end{array}$ \\
\hline Divorced & $\begin{array}{c}0.200 \\
(0.243)\end{array}$ & $\begin{array}{c}0.200 \\
(0.243)\end{array}$ & $\begin{array}{c}0.201 \\
(0.243)\end{array}$ & $\begin{array}{c}0.199 \\
(0.243)\end{array}$ \\
\hline Widowed & $\begin{array}{c}0.092 \\
(0.345)\end{array}$ & $\begin{array}{c}0.092 \\
(0.345)\end{array}$ & $\begin{array}{c}0.093 \\
(0.346)\end{array}$ & $\begin{array}{c}0.096 \\
(0.346)\end{array}$ \\
\hline Number of children & $\begin{array}{c}0.025 \\
(0.033)\end{array}$ & $\begin{array}{c}0.025 \\
(0.033)\end{array}$ & $\begin{array}{c}0.022 \\
(0.033)\end{array}$ & $\begin{array}{c}0.023 \\
(0.033)\end{array}$ \\
\hline Log (income) & $\begin{array}{l}0.260 * * * \\
(0.064)\end{array}$ & $\begin{array}{l}0.260 * * * \\
(0.064)\end{array}$ & $\begin{array}{l}0.261 * * * \\
(0.064)\end{array}$ & $\begin{array}{l}0.263 * * * \\
(0.064)\end{array}$ \\
\hline Full-time worker & $\begin{array}{l}0.424 * * * \\
(0.069)\end{array}$ & $\begin{array}{l}0.424 * * * \\
(0.069)\end{array}$ & $\begin{array}{l}0.423 * * * \\
(0.069)\end{array}$ & $\begin{array}{l}0.423 * * * \\
(0.069)\end{array}$ \\
\hline Part-time worker & $\begin{array}{l}0.394 * * * \\
(0.082)\end{array}$ & $\begin{array}{l}0.394 * * * \\
(0.082)\end{array}$ & $\begin{array}{l}0.392 * * * \\
(0.082)\end{array}$ & $\begin{array}{l}0.390 * * * \\
(0.082)\end{array}$ \\
\hline Vocational training & $\begin{array}{l}0.218 * * \\
(0.107)\end{array}$ & $\begin{array}{l}0.218 * * \\
(0.107)\end{array}$ & $\begin{array}{l}0.215^{* * *} \\
(0.108)\end{array}$ & $\begin{array}{l}0.213 * * \\
(0.108)\end{array}$ \\
\hline Hospital stay & $\begin{array}{r}-0.031 \\
(0.055)\end{array}$ & $\begin{array}{r}-0.031 \\
(0.055)\end{array}$ & $\begin{array}{r}-0.030 \\
(0.055)\end{array}$ & $\begin{array}{r}-0.030 \\
(0.055)\end{array}$ \\
\hline $\log ($ doctor visits +1$)$ & $\begin{array}{c}-0.074 * * * \\
(0.017)\end{array}$ & $\begin{array}{c}-0.074 * * * \\
(0.017)\end{array}$ & $\begin{array}{c}-0.074 * * * \\
(0.017)\end{array}$ & $\begin{array}{c}-0.074 * * * \\
(0.017)\end{array}$ \\
\hline Total concentration of immigrants & & $\begin{array}{c}0.039 \\
(0.952)\end{array}$ & & \\
\hline Concentration of employed immigrants & & & $\begin{array}{c}2.122 * \\
(1.177)\end{array}$ & $\begin{array}{l}2.107^{*} \\
(1.177)\end{array}$ \\
\hline Concentration of unemployed immigrants & & & $\begin{array}{c}-1.339 * * * \\
(0.496)\end{array}$ & $\begin{array}{c}-1.346^{* * * *} \\
(0.496)\end{array}$ \\
\hline Concerned about foreigners' situation & & & & $\begin{array}{r}-0.071^{*} \\
(0.043)\end{array}$ \\
\hline
\end{tabular}


Table 4 (continued)

\begin{tabular}{lllll}
\hline Variables & \multicolumn{3}{l}{} \\
\hline Constant & $9.360 * * *$ & $9.384 * * *$ & $7.621 * * *$ & $7.591 * * *$ \\
& $(1.089)$ & $(1.237)$ & $(1.420)$ & $(1.419)$ \\
Observations & 11,262 & 11,262 & 11,262 & 11,262 \\
Number of individuals & 4444 & 4444 & 4444 & 4444 \\
Within $R^{2}$ & 0.038 & 0.038 & 0.040 & 0.040
\end{tabular}

Robust standard errors in parentheses $(* * * p<0.01$, **p $<<0.05$, *p $<<0.1$ ). Immigrants who never married and are not employed are the reference group

interplay of the direct impact of subjective perceptions of cultural assimilation on immigrants' happiness from the indirect effect of a regional-level, general openness toward foreign-born persons.

Our first empirical observation reveals that the concentration of immigrants has no statistically significant impact on life satisfaction, but the effects of German identity and language proficiency remain unaltered. Cultural assimilation is an internal mechanism, based on perceptions and not indirectly influenced by external conditions. A further, more detailed analysis adds that when we distinguish the level of concentration of immigrants by employment status, external social conditions start to matter for the well-being of immigrants, insofar as they represent the potential contributions of immigrants to the society in which they live. If immigrants in the region contribute to the labor force, it positively affects their happiness, but greater unemployment is detrimental to immigrants' well-being. We measured these two effects with the concentration of employed immigrants and the concentration of unemployed immigrants, respectively. Individual-level variables capturing cultural assimilation also affirm their importance in explaining the well-being of immigrants, and these results remain robust to the inclusion of a proxy for perceived discrimination, which shows the expected negative sign

\subsection{Robustness checks}

We conducted several sensitivity analyses to check the robustness of our results. All the results discussed in this section are available on request. First, we reestimated our model, using a fixed effect probit-adapted ordinary least squares (FE-POLS) approach, as developed by van Praag and Ferrer-i-Carbonell (2008). This approach circumvents violations of the cardinality assumption and is computationally easier than an ordered probit. It uses a "rough cardinalization" of the ordered life satisfaction variable and calculates the relative cumulative frequencies of life satisfaction and the corresponding $z$ scores. For each original variable, the value of the roughly cardinalized life satisfaction variable comes from taking the conditional expectation of a standard, normally distributed, continuous variable, given the original ordering (for an example, see Cornelißen 2009). The results using this FE-POLS approach, reported in Table 5, are qualitatively the same as those obtained with an FE-OLS approach. 
Table 5 Life satisfaction of immigrants (SOEP 1985-2003)—estimation using the probit-adapted OLS method (POLS) with individual and time $\mathrm{FE}$

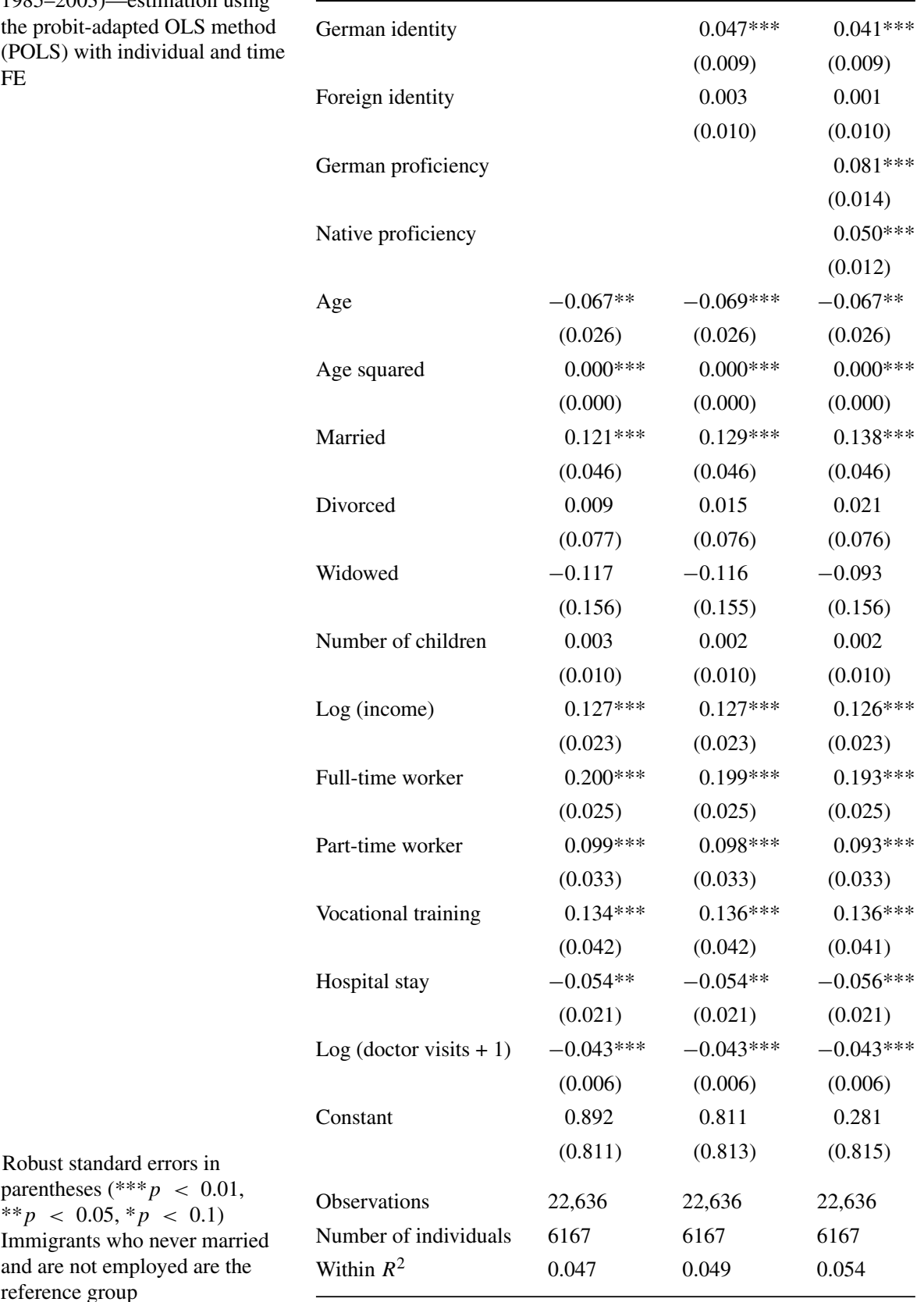

Second, in Table 6 we checked if the results might be driven by particular groups of immigrants. Immigrants coming from other German-speaking countries might be very different from other immigrants, because their culture is more similar to that
Variables 
Table 6 Life satisfaction of immigrants (SOEP 1985-2003)—estimation with individual and time FE

\begin{tabular}{|c|c|c|c|c|c|}
\hline Variables & $(1)$ & (2) & (3) & (4) & (5) \\
\hline German identity & $\begin{array}{l}0.080^{* * * *} \\
(0.020)\end{array}$ & $\begin{array}{l}0.085^{* * *} \\
(0.021)\end{array}$ & $\begin{array}{l}0.098^{* * * *} \\
(0.035)\end{array}$ & $\begin{array}{l}0.085^{* * * *} \\
(0.018)\end{array}$ & $\begin{array}{l}0.065^{* * * *} \\
(0.020)\end{array}$ \\
\hline Foreign identity & $\begin{array}{c}0.009 \\
(0.020)\end{array}$ & $\begin{array}{c}0.015 \\
(0.023)\end{array}$ & $\begin{array}{r}-0.030 \\
(0.032)\end{array}$ & $\begin{array}{c}0.004 \\
(0.019)\end{array}$ & $\begin{array}{c}0.023 \\
(0.020)\end{array}$ \\
\hline German proficiency & $\begin{array}{l}0.158 \text { *** } \\
(0.028)\end{array}$ & $\begin{array}{l}0.170 * * * \\
(0.030)\end{array}$ & $\begin{array}{l}0.125^{* *} \\
(0.053)\end{array}$ & $\begin{array}{l}0.163^{* * *} \\
(0.027)\end{array}$ & $\begin{array}{l}0.156^{* * * *} \\
(0.028)\end{array}$ \\
\hline Native proficiency & $\begin{array}{l}0.100 * * * \\
(0.026)\end{array}$ & $\begin{array}{l}0.106^{* * * *} \\
(0.029)\end{array}$ & $\begin{array}{c}0.076^{*} \\
(0.040)\end{array}$ & $\begin{array}{l}0.097 * * * \\
(0.024)\end{array}$ & $\begin{array}{l}0.100 * * * \\
(0.026)\end{array}$ \\
\hline Age & $\begin{array}{r}-0.077 \\
(0.052)\end{array}$ & $\begin{array}{r}-0.069 \\
(0.053)\end{array}$ & $\begin{array}{c}-0.449 * * * \\
(0.154)\end{array}$ & $\begin{array}{r}-0.098^{*} \\
(0.051)\end{array}$ & $\begin{array}{r}-0.076 \\
(0.052)\end{array}$ \\
\hline Age squared & $\begin{array}{l}0.000^{* * * *} \\
(0.000)\end{array}$ & $\begin{array}{l}0.000 * * * \\
(0.000)\end{array}$ & $\begin{array}{l}0.002^{* * *} \\
(0.000)\end{array}$ & $\begin{array}{l}0.001 * * * \\
(0.000)\end{array}$ & $\begin{array}{l}0.000^{* * *} \\
(0.000)\end{array}$ \\
\hline Married & $\begin{array}{l}0.207 * * \\
(0.101)\end{array}$ & $\begin{array}{l}0.208 * \\
(0.109)\end{array}$ & $\begin{array}{l}0.451^{* * * *} \\
(0.130)\end{array}$ & $\begin{array}{l}0.289 * * * \\
(0.085)\end{array}$ & $\begin{array}{l}0.205^{* *} \\
(0.101)\end{array}$ \\
\hline Divorced & $\begin{array}{r}-0.099 \\
(0.168)\end{array}$ & $\begin{array}{r}-0.083 \\
(0.183)\end{array}$ & $\begin{array}{c}0.248 \\
(0.265)\end{array}$ & $\begin{array}{c}0.034 \\
(0.152)\end{array}$ & $\begin{array}{r}-0.118 \\
(0.167)\end{array}$ \\
\hline Widowed & $\begin{array}{r}-0.182 \\
(0.351)\end{array}$ & $\begin{array}{r}-0.293 \\
(0.383)\end{array}$ & $\begin{array}{c}0.483 \\
(0.613)\end{array}$ & $\begin{array}{r}-0.122 \\
(0.334)\end{array}$ & $\begin{array}{r}-0.179 \\
(0.351)\end{array}$ \\
\hline Number of children & $\begin{array}{c}0.012 \\
(0.021)\end{array}$ & $\begin{array}{c}0.014 \\
(0.023)\end{array}$ & $\begin{array}{r}-0.024 \\
(0.038)\end{array}$ & $\begin{array}{c}0.011 \\
(0.020)\end{array}$ & $\begin{array}{c}0.008 \\
(0.021)\end{array}$ \\
\hline Log (income) & $\begin{array}{l}0.284 * * * \\
(0.051)\end{array}$ & $\begin{array}{l}0.268 * * * \\
(0.054)\end{array}$ & $\begin{array}{l}0.254^{* * * *} \\
(0.080)\end{array}$ & $\begin{array}{l}0.273 * * * \\
(0.046)\end{array}$ & $\begin{array}{l}0.283^{* * *} \\
(0.051)\end{array}$ \\
\hline Full-time worker & $\begin{array}{l}0.441 * * * \\
(0.055)\end{array}$ & $\begin{array}{l}0.453^{* * * *} \\
(0.059)\end{array}$ & $\begin{array}{l}0.287 * * * \\
(0.085)\end{array}$ & $\begin{array}{l}0.410 * * * \\
(0.050)\end{array}$ & $\begin{array}{l}0.444 * * * \\
(0.055)\end{array}$ \\
\hline Part-time worker & $\begin{array}{l}0.209^{* * *} \\
(0.070)\end{array}$ & $\begin{array}{l}0.186^{* *} \\
(0.081)\end{array}$ & $\begin{array}{l}0.252^{* * * *} \\
(0.094)\end{array}$ & $\begin{array}{l}0.202 * * * \\
(0.064)\end{array}$ & $\begin{array}{l}0.210^{* * *} \\
(0.070)\end{array}$ \\
\hline Vocational training & $\begin{array}{l}0.307^{* * *} \\
(0.109)\end{array}$ & $\begin{array}{l}0.344 * * \\
(0.134)\end{array}$ & $\begin{array}{c}0.156^{*} \\
(0.093)\end{array}$ & $\begin{array}{l}0.268^{* * * *} \\
(0.077)\end{array}$ & $\begin{array}{l}0.312 * * * \\
(0.110)\end{array}$ \\
\hline Hospital stay & $\begin{array}{c}-0.130^{* * * *} \\
(0.045)\end{array}$ & $\begin{array}{c}-0.143 * * * \\
(0.049)\end{array}$ & $\begin{array}{r}-0.033 \\
(0.078)\end{array}$ & $\begin{array}{c}-0.125^{* * *} \\
(0.042)\end{array}$ & $\begin{array}{c}-0.130^{* * *} \\
(0.045)\end{array}$ \\
\hline $\log ($ doctor visits +1$)$ & $\begin{array}{c}-0.086^{* * * *} \\
(0.012)\end{array}$ & $\begin{array}{c}-0.092 * * * \\
(0.013)\end{array}$ & $\begin{array}{c}-0.050 * * \\
(0.021)\end{array}$ & $\begin{array}{c}-0.083^{* * *} \\
(0.011)\end{array}$ & $\begin{array}{c}-0.084^{* * *} \\
(0.012)\end{array}$ \\
\hline $\begin{array}{l}\text { Share of immigrants from } \\
\text { the same country }\end{array}$ & & & & $\begin{array}{l}-1.083 * \\
(0.656)\end{array}$ & \\
\hline Plan to stay in Germany forever & & & & & $\begin{array}{l}0.228 * * * \\
(0.037)\end{array}$ \\
\hline Constant & $\begin{array}{l}5.816^{* * * *} \\
(1.727)\end{array}$ & $\begin{array}{l}5.574 * * * \\
(1.829)\end{array}$ & $\begin{array}{l}13.514 * * * \\
(3.251)\end{array}$ & $\begin{array}{l}6.594 * * * \\
(1.569)\end{array}$ & $\begin{array}{l}5.681 * * * \\
(1.728)\end{array}$ \\
\hline Observations & 19,873 & 16,492 & 6144 & 22,518 & 19,846 \\
\hline
\end{tabular}


Table 6 (continued)

\begin{tabular}{llllll}
\hline Variables & $(1)$ & $(2)$ & $(3)$ & $(4)$ & $(5)$ \\
\hline Number of individuals & 5164 & 3533 & 2634 & 6121 & 5157 \\
Within $R^{2}$ & 0.049 & 0.052 & 0.055 & 0.050 & 0.052 \\
\hline
\end{tabular}

In column (1), we exclude immigrants from German speaking countries. In column (2), we keep only immigrants from the top five origin countries. In column (3), we exclude immigrants from the top five origin countries. In column (4), we add the share of immigrants from the same country of origin. In column (5), we add a dummy equal to 1 if the immigrants plan to stay in Germany forever.

Robust standard errors in parentheses $\left(* * * p<0.01{ }^{* *} p<0.05, * p<0.1\right)$ Immigrants who never married and are not employed are the reference group

of the host country, and they face no language barrier. Therefore, we reestimated our regression from the third column of Table 2 but excluded immigrants from Austria, Luxembourg, or Switzerland and those born in Germany. The coefficients for the German identity and German proficiency variables decreased slightly (0.080 and 0.158 , respectively) but the results stayed qualitatively unchanged. We also tried excluding or only including immigrants from the top five origin countries (Turkey, ex-Yugoslavia, Greece, Italy, and Spain). In both cases, we confirmed our results; if anything, the effect of cultural assimilation with the host culture grew even more important when we excluded immigrants who came from these top five countries of origin. A variable that assigned, to each individual and year, the share of immigrants from the same country in that year (computed from the SOEP data) exerted a negative effect on life satisfaction (at the $10 \%$ significance level), but the effects of the other variables remained the same.

Third, because we include many years of data, panel mortality might lead to a selectivity bias. For example, immigrants who are not well integrated in Germany or are not satisfied with their life might decide to return to their country of origin and drop out of our sample. Therefore, we checked whether attrition bias is a problem, by applying Verbeek and Nijman's 1992 methodology, which consists of adding selectivity dummies to the main equation of interest. The selectivity dummy in year $t$ for individual $i$ equals 1 if that person participates to the survey in year $t$ and also in year $t+1$, while it is equal to 0 if the person drops out of the sample. With the null hypothesis of no selective attrition, selectivity dummies should be jointly insignificant, which we can test with a simple $F$ test. In our case, we fail to reject the null hypothesis (for the specification in column 3 of Table 2, the $p$ value for the selectivity dummies is 0.4342); therefore, attrition bias is not an issue. Our results are in line with those of Abolhassani and Alessie (2013), who also do not find evidence of attrition when using the SOEP data to study life satisfaction around retirement. As a further check, we considered whether the immigrant was planning to return to the country of origin by adding a dummy variable, equal to 1 if the immigrant planned to stay in Germany forever and 0 otherwise (last column of Table 6). This variable was significantly associated with life satisfaction, but the other results remained qualitatively unchanged. The effect of German identity fell somewhat (coefficient $=0.065)$, 
Table 7 Life satisfaction of immigrants (1995-2003)—estimation with individual and time FE. Robustness of the results to the inclusion of the percentage of extreme right-wing votes and the $(\log )$ GDP as measures for external conditions

Variables

\begin{tabular}{|c|c|c|c|c|}
\hline German identity & $\begin{array}{l}0.068 * * \\
(0.027)\end{array}$ & $\begin{array}{l}0.067 * * \\
(0.027)\end{array}$ & $\begin{array}{l}0.068 * * \\
(0.027)\end{array}$ & $\begin{array}{l}0.066 * * \\
(0.027)\end{array}$ \\
\hline Foreign identity & $\begin{array}{r}-0.018 \\
(0.026)\end{array}$ & $\begin{array}{r}-0.018 \\
(0.026)\end{array}$ & $\begin{array}{r}-0.018 \\
(0.026)\end{array}$ & $\begin{array}{r}-0.018 \\
(0.026)\end{array}$ \\
\hline German proficiency & $\begin{array}{l}0.111^{* * * *} \\
(0.037)\end{array}$ & $\begin{array}{l}0.108 * * * \\
(0.037)\end{array}$ & $\begin{array}{l}0.111 \text { *** } \\
(0.037)\end{array}$ & $\begin{array}{l}0.109 * * * \\
(0.037)\end{array}$ \\
\hline Native proficiency & $\begin{array}{l}0.087 * * \\
(0.034)\end{array}$ & $\begin{array}{l}0.087 * * \\
(0.034)\end{array}$ & $\begin{array}{l}0.087 * * \\
(0.034)\end{array}$ & $\begin{array}{l}0.087 * * \\
(0.034)\end{array}$ \\
\hline Age & $\begin{array}{c}-0.189 * * * \\
(0.035)\end{array}$ & $\begin{array}{c}-0.141^{* * * *} \\
(0.043)\end{array}$ & $\begin{array}{c}-0.178 * * * \\
(0.033)\end{array}$ & $\begin{array}{c}-0.130 * * * \\
(0.042)\end{array}$ \\
\hline Age squared & $\begin{array}{l}0.001 * * * \\
(0.000)\end{array}$ & $\begin{array}{l}0.001 * * * \\
(0.000)\end{array}$ & $\begin{array}{l}0.001 * * * \\
(0.000)\end{array}$ & $\begin{array}{l}0.001 * * * \\
(0.000)\end{array}$ \\
\hline Married & $\begin{array}{l}0.396^{* * * *} \\
(0.153)\end{array}$ & $\begin{array}{l}0.404 * * * \\
(0.153)\end{array}$ & $\begin{array}{l}0.398 * * * \\
(0.153)\end{array}$ & $\begin{array}{l}0.406^{* * *} \\
(0.153)\end{array}$ \\
\hline Divorced & $\begin{array}{c}0.198 \\
(0.243)\end{array}$ & $\begin{array}{c}0.199 \\
(0.243)\end{array}$ & $\begin{array}{c}0.198 \\
(0.243)\end{array}$ & $\begin{array}{c}0.199 \\
(0.243)\end{array}$ \\
\hline Widowed & $\begin{array}{c}0.097 \\
(0.345)\end{array}$ & $\begin{array}{c}0.098 \\
(0.346)\end{array}$ & $\begin{array}{c}0.095 \\
(0.345)\end{array}$ & $\begin{array}{c}0.095 \\
(0.346)\end{array}$ \\
\hline Number of children & $\begin{array}{c}0.025 \\
(0.033)\end{array}$ & $\begin{array}{c}0.022 \\
(0.033)\end{array}$ & $\begin{array}{c}0.026 \\
(0.033)\end{array}$ & $\begin{array}{c}0.023 \\
(0.033)\end{array}$ \\
\hline Log (income) & $\begin{array}{l}0.261 * * * \\
(0.064)\end{array}$ & $\begin{array}{l}0.263^{* * * *} \\
(0.064)\end{array}$ & $\begin{array}{l}0.262 * * * \\
(0.064)\end{array}$ & $\begin{array}{l}0.263^{* * *} \\
(0.064)\end{array}$ \\
\hline Full-time worker & $\begin{array}{l}0.423 * * * \\
(0.069)\end{array}$ & $\begin{array}{l}0.422^{* * *} \\
(0.069)\end{array}$ & $\begin{array}{l}0.423^{* * *} \\
(0.069)\end{array}$ & $\begin{array}{l}0.423^{* * *} \\
(0.069)\end{array}$ \\
\hline Part-time worker & $\begin{array}{l}0.392 * * * \\
(0.082)\end{array}$ & $\begin{array}{l}0.390 * * * \\
(0.082)\end{array}$ & $\begin{array}{l}0.392 * * * \\
(0.082)\end{array}$ & $\begin{array}{l}0.390 * * * \\
(0.082)\end{array}$ \\
\hline Vocational training & $\begin{array}{l}0.216^{* *} \\
(0.107)\end{array}$ & $\begin{array}{l}0.213 * * \\
(0.108)\end{array}$ & $\begin{array}{l}0.216^{* * *} \\
(0.107)\end{array}$ & $\begin{array}{l}0.213^{* *} \\
(0.108)\end{array}$ \\
\hline Hospital stay & $\begin{array}{r}-0.031 \\
(0.055)\end{array}$ & $\begin{array}{r}-0.031 \\
(0.055)\end{array}$ & $\begin{array}{r}-0.031 \\
(0.055)\end{array}$ & $\begin{array}{r}-0.031 \\
(0.055)\end{array}$ \\
\hline $\log ($ doctor visits +1$)$ & $\begin{array}{c}-0.074 * * * \\
(0.017)\end{array}$ & $\begin{array}{c}-0.074 * * * \\
(0.017)\end{array}$ & $\begin{array}{c}-0.074 * * * \\
(0.017)\end{array}$ & $\begin{array}{c}-0.074 * * * \\
(0.017)\end{array}$ \\
\hline Concentration of employed immigrants & & $\begin{array}{l}2.084^{*} \\
(1.180)\end{array}$ & & $\begin{array}{l}2.174^{*} \\
(1.199)\end{array}$ \\
\hline Concentration of unemployed immigrants & & $\begin{array}{c}-1.356 \text { *** } \\
(0.496)\end{array}$ & & $\begin{array}{c}-1.349 * * * \\
(0.496)\end{array}$ \\
\hline Concerned about foreigners' situation & $\begin{array}{r}-0.071 * \\
(0.043)\end{array}$ & $\begin{array}{r}-0.072 * \\
(0.043)\end{array}$ & $\begin{array}{r}-0.070 \\
(0.043)\end{array}$ & $\begin{array}{r}-0.071 * \\
(0.043)\end{array}$ \\
\hline
\end{tabular}


Table 7 (continued)

\begin{tabular}{lcccc} 
Variables \\
\hline Percentage of extreme right-wing votes & 0.017 & 0.020 & & \\
& $(0.031)$ & $(0.032)$ & & \\
Log (GDP) & & & -0.121 & -0.190 \\
& & & $(0.725)$ & $(0.738)$ \\
Constant & $9.664^{* * * *}$ & $7.915^{* * *}$ & 10.524 & 9.453 \\
& $(1.204)$ & $(1.460)$ & $(7.038)$ & $(7.274)$ \\
Observations & 11,262 & 11,262 & 11,262 & 11,262 \\
Number of individuals & 4444 & 4444 & 4444 & 4444 \\
Within $R^{2}$ & 0.039 & 0.040 & 0.039 & 0.040 \\
\hline
\end{tabular}

Robust standard errors in parentheses $\left(* * * p<0.01,{ }^{* *} p<0.05, * p<0.1\right)$. Immigrants who never married and are not employed are the reference group

probably due to the relatively high correlation between the feeling of identification with the German culture and the wish to stay in Germany forever.

Fourth, we used other proxies for the openness of the region to immigration and general external conditions. A potential criticism of immigrant concentration variables in previous analyses is that they might be interpreted as enclave measures: New immigrants tend to settle in areas where there are other immigrants. In our case, this issue is less of a concern, because the regions we study are quite large. However, we used the share of extreme right-wing votes in parliamentary elections at the state level as an alternative measure of regional openness to immigration. Following Knabe et al. (2013), we obtained data from the German Federal Returning Office and constructed a new variable that combined the share of all votes for four extreme right-wing parties: the Republikaner (REP), the Deutsche Volksunion (DVU), the Nationaldemokratische Partei Deutschlands (NPD), and the Partei Rechtsstaatlicher Offensive (Schill-Partei). State-level elections occur every 4 years, so we had data about 1994, 1998, and 2002. We assigned the 1994 election results, by state, to the 1993 and 1995 waves of SOEP; those from 1998 to the 1997 and 1999 waves; and the results from 2002 to the 2001 and 2003 waves. Table 7 shows that the coefficient of the share of extreme right-wing votes appeared insignificant, and our other results remained unchanged, possibly due to the low variability of this measure in our sample. We also tried to add the regional gross domestic product (GDP) per capita at current prices to the regression, ${ }^{19}$ but its effect was insignificant. We already had included time dummies in the regressions, and the time trend of the GDP per capita did not differ much across regions in the era we study.

\footnotetext{
${ }^{19}$ These data, collected by the Federal Statistical Office, can be freely downloaded from www.vgrdl.de/ Arbeitskreis_VGR/ergebnisse.asp.
} 


\section{Conclusion}

Immigration is an increasingly important phenomenon for European societies and also across the Atlantic, especially if it fuels risks of social instability. A recent OECD (2013) report on international migration suggests that the issue of cultural dissimilation determines how well a society can tackle the phenomenon. From this perspective, our analysis adds an important contribution to current academic and policy discussions, by highlighting the link between a self-reported but direct measure of cultural assimilation and the subjective well-being of immigrants. ${ }^{20}$

Our contribution goes beyond previous socio-economic research, with two main novel results. First, we indicate a direct association between cultural assimilation and immigrants' subjective well-being, unmediated by labor market outcomes (e.g., employment status, wages), time-invariant unobserved individual characteristics, or regional controls that capture the external social conditions of immigrants. Second, we show that the potential benefits of cultural assimilation go beyond the time dimension of the integration process, as widely debated in sociological literature, because its association with life satisfaction is stronger for established immigrants than for recent ones.

The analysis thus has some important policy implications. Successful immigration policies must account for the fundamental issue of cultural assimilation. Proper interventions to facilitate cultural assimilation (e.g., language courses, interventions to limit ethnic enclaves, civic and cultural activities to foster interactions between migrants and natives, educational programs) may have great potential in terms of increasing immigrants' well-being. This issue is particularly urgent in Germany, where in recent years, "the political class had begun to accept that Germany is an immigration country with a responsibility to integrate immigrants fully into national life." 21

Acknowledgments We thank the Editor and three anonymous referees for their constructive comments. We are also grateful to Marco Bertoni, Jochen Mierau, Tobias Stöhr and participants at the NORFACE Migration Conference "Migration: Global Development, New Frontiers" (London, 2013) and the Spring Meeting of Young Economists (Aarhus, 2013) for helpful suggestions.

Open Access This article is distributed under the terms of the Creative Commons Attribution License which permits any use, distribution, and reproduction in any medium, provided the original author(s) and the source are credited.

\footnotetext{
${ }^{20}$ In a working paper, Pakrashi and Frijters (2013) investigate the relationship between life satisfaction and the assimilation of immigrants to Australia. Without a direct measure of social assimilation, they assume that the more immigrants' life satisfaction co-moves with that of natives, the more integrated they are. With this assumption, the authors find that new immigrants (recently moved to Australia) are more affected by changes in life satisfaction in their country of origin, rather than in their country of residence. However, co-movement in life satisfaction with respect to native Australians occurs after just a year.

${ }^{21}$ See "The integration debate in Germany. Is multi-kulty dead?" (http://www.economist.com/blogs/ newsbook/2010/10/integration_debate_germany/print)
} 


\section{References}

Abolhassani M, Alessie R (2013) Subjective well-being around retirement. De Economist 161(3):349-366 Amit K (2010) Determinants of life satisfaction among immigrants from Western countries and from the FSU in Israel. Soc Indic Res 96(3):515-534

Angelini V, Cavapozzi D, Corazzini L, Paccagnella O (2014) Do Danes and Italians rate life satisfaction in the same way? Using vignettes to correct for individual-specific scale biases. Oxford B Econ Stat 76(5):643-666

Baltatescu S (2007) Central and Eastern Europeans migration' subjective quality of life. A comparative study. J Int Migr Stud 1(2):67-81

Bartram D (2010) Economic migration and happiness: comparing immigrants' and natives' happiness gains from income. Soc Indic Res 103(1):57-76

Bauer TK, Dietz B, Zimmermann KF, Zwintz E (2005) German migration: development, assimilation, and labour market effects. In: Zimmermann KF (ed) European Migration. What do we know? Oxford University Press, Oxford

Bauer TK, Lofstrom M, Zimmermann KF (2000) Immigration policy, assimilation of immigrants and natives' sentiments towards immigrants: evidence from 12 OECD countries. Swedish Econ Pol Rev 7(2):11-53

Bianchi M, Buonanno P, Pinotti P (2012) Do immigrants cause crime? J Eur Econ Assoc 10(6):1318-1347

Bisin A, Patacchini E, Verdier T, Zenou Y (2011) Ethnic identity and labour market outcomes of immigrants in Europe. Econ Policy 26(65):57-92

Blanchflower DG, Oswald A (2008) Is well-being U-shaped over the life-cycle? Soc Sci Med 66(8):17331749

Borjas GJ (1994) The economics of immigration. J Econ Lit 32(4):1667-1717

Bruni L, Porta PL (2005) Economics and happiness. Framing the analysis. Oxford University Press, Oxford

Card D, Dustmann C, Preston I (2012) Immigration, wages, and compositional amenities. J Eur Econ Assoc 10(1):78-119

Carliner G (1980) Wages, earnings and hours of first, second, and third generation American males. Econ Inq 18(1):87-102

Casey T, Dustmann C (2010) Immigrants' identity, economic outcomes and the transmission of identity across generations. Econ J 120(542):31-51

Chiswick BR (1978) The effect of Americanization on the earnings of foreign-born men. J Polit Econ 86(5):897-921

Clark AE, Diener E, Georgellis Y, Lucas RE (2008) Lags and leads in life satisfaction: a test of the baseline hypothesis. Econ J 118(529):F222-F243

Constant AF, Gataullina L, Zimmermann L, Zimmermann KF (2006) Clash of cultures: Muslims and Christians in the ethnosizing process. IZA Discussion Paper 2350

Constant AF, Massey DS (2005) Labour market segmentation and the earnings of German guestworkers. Popul Res Policy Rev 24(5):489-512

Constant AF, Roberts R, Zimmermann KF (2009) Ethnic identity and immigrant homeownership. Urban Stud 46(9):1879-1898

Constant AF, Zimmermann KF (2008) Measuring ethnic identity and its impact on economic behaviour. J Eur Econ Assoc 6(2-3):424-433

Constant AF, Zimmermann KF (2009a) Ethnosizing immigrants. J Econ Behav Organ 69(3):274-287

Constant AF, Zimmermann KF (2009b) Work and money: payoffs by ethnic identity and gender. Res Lab E 29:3-30

Constant AF, Zimmermann KF (2013) International handbook on the economics of migration. Edward Elgar Publishing Ltd, Cheltenham

Cornelißen T (2009) The interaction of job satisfaction, job search, and job changes. An empirical investigation with German panel data. J Happiness Stud 10(3):367-384

Danzer AM, Yaman F (2013) Do ethnic enclaves impede immigrants' integration? Evidence from a quasiexperimental social-interaction approach. Rev Int Econ 21(2):311-325

Diener E (1984) Subjective well-being. Psychol Bull 95(3):542-575

Dolan P, Peasgood T, White M (2008) Do we really know what makes us happy? A review of the economic literature on the factors associated with subjective well-being. J Econ Psychol 29(1):94-122

Dustmann C (1994) Speaking fluency, writing fluency and earnings of migrants. J Popul Econ 7(2):133156 
Dustmann C (1996) The social assimilation of immigrants. J Popul Econ 9(1):37-54

Ferrer-i-Carbonell A, Frijters P (2004) How important is methodology for the estimates of the determinants of happiness Econ J 114(497):641-659

Fertig M, Schurer S (2007) Earnings assimilation of immigrants in Germany: the importance of heterogeneity and attrition bias. SOEPpapers 30 DIW Berlin

Finch BK, Kolody B, Vega WA (2000) Perceived discrimination and depression among Mexican-origin adults in California. J Health Soc Behav 41(3):295-313

Frattini T, Dustmann C (2013) Immigration: the European experience. In: Card D, Raphael S (eds) Immigration, poverty, and socioeconomic inequality. Russell Sage Foundation

Frey BS, Stutzer A (2002a) Happiness and economics: how the economy and institutions affect well-being. Princeton University Press, Princeton

Frey BS, Stutzer A (2002b) What can economists learn from happiness research? J Econ Lit 40(2):402_ 435

Graham C, Nikolova M (2015) Bentham or Aristotle in the development process? An empirical investigation of capabilities and subjective well-being. World Dev 68:163-179

Gundel S, Peters H (2007) Assimilation and cohort effects for German immigrants. SOEPpapers 64 DIW Berlin

Harris JR, Todaro MP (1970) Migration, unemployment and development: a two-sector analysis. Am Econ Rev 60(1):126-142

Helliwell JF, Layard R, Sachs JD (2013) Introduction. World Happiness Report 2013

Herrero J, Fuente A, Gracia E (2011) Covariates of subjective well-being among Latin American immigrants in Spain: the role of social integration in the community. J Community Psychol 39(7):761775

Holland PW, Wainer H (1993) Differential item functioning. Erlbaum, Hillsdale

Hughes M, Demo DH (1989) Self-perceptions of Black Americans: self-esteem and personal efficacy. Am J Sociol 95(1):132-159

Kahneman D, Deaton A (2010) High income improves evaluation of life but not emotional well-being. P Natl Acad Sci USA 107(38):16489-16493

Kahneman D, Krueger AB (2006) Developments in the measurement of subjective well-being. J Econ Perspect 20(1):3-24

Kantarevic J (2004) Interethnic marriages and economic assimilation of immigrants. IZA Discussion Paper 1142

Knabe A, Rätzel S, Thomsen SL (2013) Right-wing extremism and the well-being of immigrants. Kyklos 66(4):567-590

Layard R (2005) Happiness: lessons from a new science. Penguin, London

Licht G, Steiner V (1994) Assimilation, labour market experience, and earnings profiles of temporary and permanent immigrant workers in Germany. Int Rev Appl Econ 8(2):130-156

Martinez R, Lee M (2000) On immigration and crime. In: LaFree G. (ed) Criminal justice: the changing nature of crime. National Institute of Justice, Washington

OECD (2013) International migration outlook 2013. OECD Publishing

Ortega J (2000) Pareto-improving immigration in an economy with equilibrium unemployment. Econ J 110(460):92-112

Ottaviano G, Peri G (2006) The economic value of cultural diversity: evidence from US cities. J Econ Geogr 6(1):9-44

Pakrashi D, Frijters P (2013) Happiness assimilation amongst migrants: evidence from Australia. Mimeo

Pischke JS (1992) Assimilation and the earnings of guestworkers in Germany. ZEW Discussion Paper Series $92-17$

Ricard M (2007) Happiness: a guide to developing life's most important skill. Little, Brown and Company, New York

Rumbaut RG (1994) The crucible within: ethnic identity, self-esteem, and segmented assimilation among children of immigrants. Int Migr Rev 28(4):748-794

Sachs JD (2013) Restoring virtue ethics in the quest for happiness. World Happiness Report 2013

Safi M (2010) Immigrants' life satisfaction in Europe: between assimilation and discrimination. Eur Sociol Rev 26(2):159-176

Schmidt CM (1993) The earnings dynamics of immigrant labour. CEPR Discussion Paper 763

Schmidt CM (1997) Immigrant performance in Germany: labour earnings of ethnic German migrants and foreign guestworkers. Q Rev Econ Financ 37(1):379-397 
Sellers RM, Caldwell CH, Schmeelk-Cone KH, Zimmerman MA (2003) Racial identity, racial discrimination, perceived stress, and psychological distress among African American young adults. J Health Soc Behav 44(3):302-317

Stark O, Jakubek M (2013) Integration as a catalyst for assimilation. Int Rev Econ Financ 28 (C):62-70

Taylor J, Turner RJ (2002) Perceived discrimination, social stress, and depression in the transition to adulthood: racial contrasts. Soc Psychol Quart 65(3):213-225

Thomas ME, Hughes M (1986) The continuing significance of race: a study of race, class, and quality of life in America, 1972-1985. Am Sociol Rev 51(6):830-841

van Praag BMS, Ferrer-i-Carbonell A (2004) Happiness quantified: a satisfaction calculus approach. Oxford University Press, Oxford

Vega WA, Rumbaut RG (1991) Ethnic minorities and mental health. Annu Rev Sociol 17:351-383

Verbeek M, Nijman T (1992) Testing for selectivity bias in panel data models. Int Econ Rev 33(3):681-703

Wagner GG, Frick JR, Schupp J (2007) The German Socio-Economic Panel Study (SOEP) - Scope, evolution and enhancements. Schmollers Jahrbuch 127:139-169

Zimmermann KF (2007) Migrant ethnic identity: concept and policy implications. Ekonomia 10(1):1-17 